\title{
Asian Pear: A Potential Alternative Fruit Crop for Growers in the Mid-Atlantic Region
}

\author{
Christopher S. Walsh', Julia M. Harshman, Anna E. Wallis, and Amy Barton Williams \\ Department of Plant Science and Landscape Architecture, 2102 Plant Sciences Building, \\ University of Maryland, College Park, MD 20742 \\ Michael J. Newell \\ Wye Research and Education Center, Maryland Agricultural Experiment Station, 124 \\ Wye Narrows Drive, Queenstown, MD 21658 \\ George R. (G.R.) Welsh \\ Western Maryland Research and Education Center, Maryland Agricultural Experiment \\ Station, 18330 Keedysville Road, Keedysville, MD 21756
}

Additional index words. fire blight, 'Magness' pear, pear psylla, rootstocks, precocity, fruit quality

\begin{abstract}
Production of european pears (Pyrus communis L.) in the eastern United States is limited by a number of physiological and pathological problems. In an attempt to expand sustainable pear production in that region, a series of long-term field trials of asian pear [Pyrus pyrifolia (Burm. F) Nak. (syn. Pyrus serotina L.)] were established at two sites in Maryland. To compare precocity, productivity, and survival, nine asian pear cultivars and three European cultivars were planted in a replicated trial in 2010 at the Wye Research and Education Center (Wye REC). The asian pears were precocious and productive and many trees flowered and fruited in the second leaf. After the fourth leaf, survival of 'Isi'iwasi', 'Shinsui', 'Kosui', and 'Olympic' was good, while many 'Hosui' and 'Ya Li' (asian pear) trees as well as 'Bartlett' and 'Golden Russett' (european pear) trees had died at that point, following bloom infections of fire blight (Erwinia amylovora). At Keedysville (WMREC), 18 asian pear cultivars in two established plantings were evaluated for their field tolerance to fire blight following a severe hailstorm. The cultivars Shin Li, Daisu Li, Shinsui, and Olympic fared as well as Magness, a fire blight-tolerant european pear cultivar that served as a benchmark in that evaluation. Conversely, 'Hosui', 'Choju', 'Kosui', 'Seigyoku', 'Ya Li', and 'Ts'e Li' were severely damaged. Three consumer tastings were conducted using fruit from the Wye REC trial. 'Yoinashi', 'Atago', 'Shinko', and 'Olympic' were well received by consumers. After tasting asian pears, most people, even those less familiar with the crop, reported they would consider purchasing the fruit and requested the names of local producers. Based on our long-term research results, there appears to be a good opportunity for locally produced asian pear fruit. With the correct cultivar selection for fire blight management, local growers should be able to produce this alternative crop sustainably and market their fruit profitably.
\end{abstract}

Production of european pears ( $P$. commu$n i s)$ in the eastern United States is limited by a number of pathological and physiological problems, particularly fire blight, a disease caused by E. amylovora (Burr.) Winslow et al. This bacterium appears to be indigenous to North American Rosaceous plants and was first reported in the 19th century. Although it attacks a variety of fruit crops, european pears are particularly susceptible to tree damage and death from the disease (Van der Zwet and Kiel, 1979).

Received for publication 22 Dec. 2015. Accepted for publication 21 July 2016.

This paper was part of the colloquium "Alternative Specialty Crop: Opportunities and Challenges," presented at the 2015 ASHS Conference, New Orleans, LA, on 4 Aug. 2015, and sponsored by the Working Group of Asian Horticulture, Tropical Horticulture Working Group, and Pomology Working Group.

This work was supported by formula funding provided Maryland Agriculture Experiment Station, competitive funding from MAES' Competitive Grants Program and the Harry R. Hughes Center for Agro-Ecology, Inc.

We thank the many agricultural technicians and students for their assistance in managing the trees used in this study and Kathleen W. Hunt for her help organizing the taste testing at Clarksville and for preparing and editing the final manuscript.

${ }^{1}$ Corresponding author. E-mail: cswalsh@umd.edu.
'Bartlett' (syn. 'Williams Bon Chretien') has been the primary pear cultivar grown in North America for more than a century. O'Rourke (2012) reported that $\approx 47 \%$ of U.S. commercial production was accounted for by a single cultivar, Bartlett, with an additional three cultivars, Beurre Anjou (39.3\%), Beurre Bosc (11.3\%), and Doyenne du Comice (1\%) accounting for the majority of the remaining production. Although 'Bartlett' is well liked for its buttery fruit texture, flavor, canning value, and tree productivity, it is susceptible to fire blight. Hedrick (1921) stated "the trees blight badly, and are not much above average in resistance to blight, the black plague of pear."

To improve pear tree survival, breeding for fire blight resistance has been a major goal of many North American pear breeding programs. Unfortunately, the sources of resistance used frequently resulted in blight-resistant trees such as 'Magness', which were difficult to crop. This lack of precocity and productivity of fire blight-tolerant european pears, coupled with the limited cold-hardiness of size-controlling Quince rootstocks have been major reasons why pear production has remained very low in the eastern United States.

In an effort to improve pollination success, precocity, and productivity in 'Magness' pear plantings, we began testing asian pear trees for their effectiveness as pollinizers for 'Magness' (Miller and Walsh, 1984). Not long after we began that initial study, we realized that asian pear might be a viable alternative crop for local fruit growers, as most cultivars were precocious and produced a marketable crop in their third leaf. This was comparable to 'Gala' and 'Fuji' apple trees on size-controlling rootstocks (data not shown).

Reimer ranked species material for fire blight almost 100 years ago (Reimer, 1915). He listed Pyrus ussuriensis as the most blight-resistant species, followed by Pyrus calleryana, Pyrus betualaefolia, $P$. pyrifolia, and $P$. communis, which was the least tolerant. Although some asian pear cultivars were tested in Maryland in the 1970s (Oitto et al., 1970; van der Zwet and Oitto, 1972), most of their work focused on older Chinese cultivars, with little testing of japanese and korean juicy pears (Nashi types). Since pear species and cultivars have been reported to vary greatly in susceptibility to fire blight, it was of interest to know how these cultivars might perform in field locations prone to severe fire blight outbreaks.

Vavilov (1951) noted that there were three distinct centers of origin for edible Pyrus in Asia; a Near Eastern Center $(P$. communis), Central Asian Center (Pyrus korshinsyki and Pyrus boissieriana), and the Chinese Center ( $P$. pyrifolia and P. ussuriensis). Since the continental climate of the 
Chinese Center more closely resembles that of the Mid-Atlantic Region and Reimer ranked that material more tolerant to fire blight, we also hypothesized that some pears from that region might be better adapted to our local conditions than $P$. communis.

During the past 30 years, we have planted and evaluated trees and fruit in five major field trials. Some of our research has been published in nonrefereed journals (Hogmire and Walsh, 1991; Walsh et al., 2011). Further disseminating the results of this research would be valuable to producers in the eastern United States, and perhaps other areas with similar growing conditions interested in establishing sustainable orchards, particularly for direct-market sales. Two of our five long-term studies are described in this paper.

\section{MATERIALS AND METHODS}

Orchard locations and research plantings. Asian pear orchards were planted at the University of Maryland's WMREC in Keedysville and the WyeREC in Queenstown. Both sites are located $\approx 100 \mathrm{~km}$ from Washington, DC. Keedysville (lat. $39^{\circ} 30^{\prime} 35.85^{\prime \prime}$ $\mathrm{N}$ long. $77^{\circ} 44^{\prime} 0.14^{\prime \prime} \mathrm{W}$ ) is located in the Piedmont Region northwest of Washington, DC, while Queenstown (lat. 38 $54^{\prime} 31.45^{\prime \prime}$ $\mathrm{N}$ long. $76^{\circ} 8^{\prime} 54.65^{\prime \prime} \mathrm{W}$ ) is located in the Atlantic Coastal Plain east of the Chesapeake Bay.

Soils at both sites are level, uniform, deep, and productive. The Keedysville soil series is Hagerstown Loam, while the soil at Wye is classified as a Mattapex-Butlerstown Silt Loam. Keedysville is located close to a traditional fruit belt and is well suited to apple production. It has a continental climate and is classified as U.S. Department of Agriculture (USDA) hardiness zone $6 \mathrm{~b}\left(-5\right.$ to $0^{\circ} \mathrm{F}$, or about -20.6 to $\left.-17.8{ }^{\circ} \mathrm{C}\right)$. Queenstown has a water-moderated climate, which is well suited to peach production and is classified as USDA Hardiness Zone $7 \mathrm{~b}\left(+5\right.$ to $10^{\circ} \mathrm{F}$, or about -15 to $-12.2{ }^{\circ} \mathrm{C}$ ).
Trial 1: Field studies of precocity, productivity, and tree survival at WyeREC. To study tree precocity and productivity, nine asian pear cultivars (Atago, Hosui, Isi'iwase, Kosui, Olympic, Shinko, Shinsui, Ya Li, and Yoinashi) and three european pear cultivars (Bartlett, Golden Russett, and Potomac) was established at Wye REC. Design was a randomized complete block consisting of five rows with individual tree replicates blocked down the row. Border rows of apple trees were set east and west of the planting. The orchard was enclosed inside electrified fencing to prevent deer damage.

Asian pear trees were propagated onto fullsized Pyrus betulaefolia rootstocks. Trees were planted at a medium density, using a $4 \times 6 \mathrm{~m}$ spacing and managed individually. Trees were hand planted in early Apr. 2010 into holes drilled with an auger, and then trained and pruned to a central-leader system. No additional support was provided.

Trees were fertilized and managed following local integrated pest management (IPM) recommendations (Pfeiffer et al., 2014). Fruitlets were removed during the second leaf to avoid stunting the trees, then hand thinned in early summer in the third and fourth leaf. Individual tree yields were collected when fruit was tree-ripe spanning the period from early August until the beginning of October (Table 1). Tree height, spread, and trunk-cross sectional area were recorded at the end of the fourth leaf.

Trial 2: Field evaluation of tree survival following hail-induced trauma blight at Keedysville. In our studies of field tolerance to fire blight, we used two established plantings at Keedsyville WMREC, which were planted and managed similarly to the trees at Wye. The first was a 1985 planting with asian pear trees set as single pollinizer trees in a 'Magness' pear rootstock trial. The second was planted in 1989 as one of the Southeastern Zonal Trial plantings organized by Prof. Caula Beyl of Alabama A\&M University. This 1989 planting consisted of ten randomized complete blocks, each with one tree of 15 asian pear cultivars.
A hailstorm in July 1994 triggered a severe fire-blight epidemic in both of these plantings. Following the hail-induced fire blight epidemic, trees were evaluated on their growth and survival in early June 1996 using a simplified version of the USDA fire blight 5 to 1 rating system (Van der Zwet and Kiel, 1979).

$5=$ Full canopy, healthy foliage

$4=$ Full canopy, some chlorotic foliage

$3=$ Significant canopy damage, more than half of the canopy remaining

$2=$ Significant canopy damage, less than half of the canopy remaining

$1=$ Dead tree

Each tree was evaluated separately by three of the authors: Amy Barton Williams, Christopher S. Walsh, and G.R. Welsh. Following these individual evaluations, a mean score was computed for each tree. Mean values for each cultivar and planting were then analyzed statistically.

Fruit quality and consumer acceptance. In 2013 and 2014 fruit from the 2010 planting at Wye REC were harvested, hand packed into tray-packed cartons, and held at $4{ }^{\circ} \mathrm{C}$ until early October. Apple and asian pear fruit slices were presented to untrained consumers during an open house at the University of Maryland Agricultural Experiment Station in Clarksville. Consumers were asked to rate the fruit objectively on a 1 (dislike extremely) to 5 (like extremely) scale for several characteristics. The traits evaluated were appearance, flesh texture, sweetness, and overall taste. Consumers were also asked whether they were willing to buy this product.

Statistical analyses. Analysis of variance was conducted using the Mixed Procedure (SAS, version 9.2; SAS Institute Inc., Cary, NC). Replication and (when appropriate) block were considered random. Means were calculated using the means statement. Mean separations were carried out using the Tukey statement option when the effect of cultivar was statistically significant $(P<0.05)$. The

Table 1. Effect of cultivar on the harvest date, tree size, cumulative yield, cumulative yield efficiency, and tree survival of 12 pear cultivars after their fourth leaf (2013) at the Wye Research and Education Center in Queenstown, MD.

\begin{tabular}{|c|c|c|c|c|c|c|c|}
\hline Variable & $\begin{array}{l}\text { Mean harvest } \\
\text { (date) }\end{array}$ & Tree ht (m) & Tree spread $(\mathrm{m})$ & $\begin{array}{c}\text { Trunk cross sectional } \\
\text { area }\left(\mathrm{cm}^{2}\right)\end{array}$ & Yield $(\mathrm{kg})$ & $\begin{array}{l}\text { Yield efficiency } \\
\left(\mathrm{kg} / \mathrm{cm}^{2}\right)\end{array}$ & Tree survival (\%) \\
\hline Shinsui & Aug. 10 & 3.8 & $1.6 \mathrm{ab}$ & $29.7 \mathrm{~b}$ & $4.8 \mathrm{~b}$ & $0.17 \mathrm{~cd}$ & 100 \\
\hline Hosui & Aug. 11 & 3.1 & $1.8 \mathrm{ab}$ & $29.1 \mathrm{~b}$ & $9.1 \mathrm{~b}$ & $0.45 \mathrm{bcd}$ & 60 \\
\hline Kosui & Aug. 17 & 3.7 & $1.6 \mathrm{ab}$ & $29.2 \mathrm{~b}$ & $4.2 \mathrm{~b}$ & $0.15 \mathrm{~d}$ & 100 \\
\hline Atago & Aug. 24 & 3.5 & $1.4 \mathrm{ab}$ & $23.5 \mathrm{~b}$ & $17.3 \mathrm{ab}$ & $0.92 \mathrm{ab}$ & 60 \\
\hline Yoinashi & Aug. 30 & 3.5 & $1.5 \mathrm{ab}$ & $27.2 \mathrm{~b}$ & $7.8 \mathrm{~b}$ & $0.34 \mathrm{~cd}$ & 80 \\
\hline $\mathrm{Ya} \mathrm{Li}$ & Oct. 1 & 3.7 & $1.7 \mathrm{ab}$ & $32.1 \mathrm{ab}$ & $17.6 \mathrm{ab}$ & $0.5 \mathrm{bcd}$ & 40 \\
\hline \multicolumn{8}{|c|}{ European pear cultivars } \\
\hline Bartlett & Sept. 4 & 3.8 & $2.2 \mathrm{ab}$ & $43.6 \mathrm{ab}$ & $6.3 \mathrm{~b}$ & $0.17 \mathrm{~cd}$ & 40 \\
\hline Golden Russett & Sept. 12 & 4.2 & $2.2 \mathrm{a}$ & $51.5 \mathrm{a}$ & $2.7 \mathrm{~b}$ & $0.04 \mathrm{~d}$ & 40 \\
\hline Potomac & - & 3.8 & $1.8 \mathrm{ab}$ & $22.8 \mathrm{~b}$ & - & - & 100 \\
\hline$P$ value & & 0.1649 & 0.0357 & 0.0067 & 0.0022 & $<0.0001$ & \\
\hline
\end{tabular}

Means followed by the same letter are not significantly different using the Tukey mean separation method $(P=0.05)$. Each column represents a separate mean separation test. 
above procedures were used to determine the effects of cultivar on fire blight susceptibility and the eating experience attributes.

\section{RESULTS AND DISCUSSION}

Field studies of tree growth, productivity, and survival at Wye REC. Field studies of nine asian pear cultivars and two European cultivars conducted at Wye REC demonstrated the early relative precocity and productivity of Asian cultivars in this region. Asian pear trees began flowering heavily in the second leaf, whereas few flowers were observed on the european pears. Production data summarizing tree size, yield, and productivity after the fourth leaf (2013 growing season) are shown in Table 1. These results are typical for asian pears planted in Maryland.

Damage from blossom blight began in the third leaf (2012) and continued to cause tree losses in 2013. As expected, more than half of the 'Bartlett' and 'Golden Russet' pear trees in this planting were lost to fire blight. Some asian pear trees, notably 'Atago' and 'Ya Li', were also lost to fire blight, whereas trees of many other asian pear cultivars survived.

Field evaluation of tree survival following hail-induced trauma blight at Keedysville. The relative field tolerance of 18 asian pear cultivars following trauma blight induced by a hail storm in 1994 is shown in Table 2. When cultivars appeared in both trials, their results appeared similar. Although no asian pear cultivar was immune to fire blight, there was a great range of tolerance among cultivars in this field evaluation. When cultivars appeared in both the 'Magness' pollinizer trial and the Southeastern Zonal Trial, results were similar. Since these plantings were set in close proximity, 'Magness' pear served as a valuable benchmark for rating the performance of all the cultivars evaluated in this trial.

In the 'Magness' pollinizer trial, 'Magness' showed the greatest tolerance to fire blight, whereas 'Ts'e Li' appeared to be the most susceptible. In the Southeastern Zonal Trial, 'Shinsui' showed the greatest field tolerance to blight, whereas 'Ya Li' was the most susceptible.

Although not detailed in this paper, an earlier effort to reduce tree losses from fire blight involved testing $P$. calleryana 'Bradford' and 'Old Home' $\times$ 'Farmingdale' $(\mathrm{OH} \times$ F) rootstocks at Wye REC (data not shown). 'Bradford' was more precocious than $P$. betulaefolia, and thus required more hand thinning. $\mathrm{OH} \times \mathrm{F}$ stocks were also associated with reduced fruit size, perhaps due to a slight reduction in tree vigor.

Based on the cumulative results of all trials, $P$. betulaefolia continues to be the recommended asian pear rootstock for the Mid-Atlantic Region.

Other production characteristics. In an organic orchard trial at Wye REC 'Olympic' and 'Niitaka' asian pears were found to be equally as productive under an organic management program as they were under an IPM
(Walsh et al., 2011). In the organic orchard trial, fire blight eventually decimated the commercial apple cultivars Gala and Fuji budded onto dwarfing rootstocks but had far less effect on the asian pears than on the apple trees. Asian pear bloom occurs about $10 \mathrm{~d}$ earlier than apple in this region. This may allow some of these cultivars to avoid blossom blight infection, as they are in bloom before the infection period predicted by the MARYBLYT program (Steiner, 1989).

Fruit quality and consumer acceptance. The consumer acceptance surveys in 2013 and 2014 using Wye REC fruit demonstrated that consumers familiar with asian pears were immediately drawn to these tastings and provided very positive feedback. Consumers less familiar with asian pears reported some awareness but had neither tasted, nor purchased the fruit previously. After tasting, most people reported they would be interested in purchasing asian pears and requested the names of local producers (Table 3).

Of the five asian pear cultivars tested, four were judged similarly by consumers for their appearance, flavor, texture, and overall flavor, whereas 'Niitaka' was judged significantly different. Although more than $80 \%$ of these potential consumers reported a willingness to purchase 'Yoinashi', 'Olympic', 'Shinko', and 'Atago' in 2013, only 46\% of these potential consumers were inclined to purchase 'Niitaka' (Table 3). During the

tasting, we measured soluble solids content ( ${ }^{\circ}$ Brix) and found 'Niitaka' to be more than 1 ${ }^{\circ}$ Brix lower than the other four cultivars. When this taste test was repeated in 2014, 'Olympic' was judged to be superior, again due to its high soluble solids content.

Other management issues. Like any crop, asian pears do have their problems. In addition to fire blight, pear psylla is another major pest that limits pear productivity and quality in the Mid-Atlantic Region. In a preliminary study of pear psylla susceptibility, Hogmire and Walsh (1991) reported that the number of psylla-days varied among pear cultivars. Although the clear-skinned cultivars, 20th Century, Shinseiki, and Seigyoku, were quite susceptible to psylla damage, Chojuro, Niitaka, Tsu-Li, and Magness were less susceptible to this pest. Trees are susceptible to deer browsing when they are young, brown marmorated stink bug feeding damage, and bird predation before harvest.

Small-fruited cultivars with clear skins, such as 'Seigyoku', 'Shinseiki', and '20th Century', have been difficult to manage in our trials (data not shown). Their small fruit size required severe hand thinning. In addition, the thin fruit skin on these cultivars is susceptible to stem punctures and postharvest marking.

The range of problems encountered when managing and handling small fruited, clearskinned asian pear cultivars thus makes it

Table 2. Field tolerance to fire blight of pear cultivars following a summer hailstorm in 1994 at Keedysville, MD. Trees were evaluated in 1996. A score of 1 indicates a dead tree and a score of 5 indicates a healthy tree.

\begin{tabular}{lcc}
\hline & & Fire blight rating \\
\cline { 2 - 3 } Cultivar & Magness pollinator planting & SE Zonal Trial \\
\hline Shinsui & - & $4.6 \mathrm{a}$ \\
Shin Li & - & $4.5 \mathrm{ab}$ \\
Daisu Li & - & $4.4 \mathrm{ab}$ \\
Olympic & $-0 \mathrm{a}$ & $4.0 \mathrm{abc}$ \\
Magness & $3.4 \mathrm{ab}$ & $3.4 \mathrm{abcd}$ \\
Niitaka & $2.5 \mathrm{abc}$ & $3.2 \mathrm{abcd}$ \\
Shinseiki (New Century) & $3.2 \mathrm{ab}$ & - \\
Okusanichi & - & $3.1 \mathrm{abcd}$ \\
Shinko & - & $3.1 \mathrm{bcd}$ \\
Shinsei & - & $2.9 \mathrm{bcde}$ \\
Chojuro & $3.0 \mathrm{abc}$ & $2.8 \mathrm{bcde}$ \\
20th Century (Nijisseiki) & - & $2.7 \mathrm{bcde}$ \\
Hosui & - & $2.3 \mathrm{de}$ \\
Choju & $2.2 \mathrm{bc}$ & - \\
Seigyoku & - & $2.2 \mathrm{de}$ \\
Kosui & - & $1.6 \mathrm{e}$ \\
Ya Li & $1.6 \mathrm{c}$ & - \\
Ts'e Li (Tsu Li) & &
\end{tabular}

Table 3. Average eating experience variables as judged by untrained consumers at the Clarksville Open House in Oct. 2013.

\begin{tabular}{lccccc}
\hline Cultivar & Appearance & Flesh texture & Sweetness & Overall taste & $\begin{array}{c}\text { People who would purchase } \\
\text { the fruit }\end{array}$ \\
\hline Yoinashi & $4.1 \mathrm{a}$ & $4.2 \mathrm{a}$ & $4.1 \mathrm{a}$ & $4.3 \mathrm{a}$ & $90.9 \% \mathrm{a}$ \\
Olympic & $4.2 \mathrm{a}$ & $4.1 \mathrm{a}$ & $4.3 \mathrm{a}$ & $4.5 \mathrm{a}$ & $87.5 \% \mathrm{a}$ \\
Shinko & $4.2 \mathrm{a}$ & $4.2 \mathrm{a}$ & $4.2 \mathrm{a}$ & $4.3 \mathrm{ab}$ & $86.8 \% \mathrm{a}$ \\
Atago & $4.0 \mathrm{a}$ & $4.1 \mathrm{a}$ & $4.0 \mathrm{a}$ & $4.0 \mathrm{~b}$ & $81.4 \% \mathrm{a}$ \\
Niitaka & $3.6 \mathrm{~b}$ & $3.5 \mathrm{~b}$ & $3.1 \mathrm{~b}$ & $3.3 \mathrm{c}$ & $45.9 \% \mathrm{~b}$ \\
$P$ value & 0.0011 & 0.0003 & $<0.0001$ & $<0.0001$ & $<0.0001$ \\
Mean SE & 0.12 & 0.13 & 0.12 & 0.12 & 0.06 \\
\hline
\end{tabular}

Means followed by the same letter are not significantly different using the Tukey mean separation method $(P=0.05)$. Each column represents a separate mean separation test. 
difficult to produce and market high-quality fruit. Consequently russet-skinned cultivars, such as 'Olympic', are better suited to the conditions encountered in the Mid-Atlantic Region. 'Olympic' has done particularly well in our trials in Maryland due to its precocity, productivity, fire blight tolerance, and fruit quality.

\section{CONCLUSION}

In nearly 30 years of research (19852014), we have identified asian pear cultivars with adequate precocity, productivity, fruit quality, and tree survival required for sustainable production in the Mid-Atlantic Region of the United States. Although asian pear trees grow vigorously following planting, they are quite precocious. Despite being propagated on a full-sized rootstock, it was not unusual to see significant flowering on trees in the second leaf, followed afterward by full production. This precocity followed by sustained, annual production, resulted in smaller tree size than would be expected from trees on a vigorous rootstock (Fig. 1).

Field tolerance to fire blight is complex and frequently varies with year and location. It is primarily determined by cultivar susceptibility and rootstock selection, which imparts vigor characteristics. Management programs and environmental conditionsprimarily temperature and humidity - are also important. In our trials, it was reassuring that tree survival and loss data following an outbreak of blossom blight at Wye REC (Table 1), corroborated the ratings of trauma blight measured following a severe hail storm at Keedysville WREC (Table 2). Similar differences in field tolerance to fire blight among these cultivars have also been seen in commercial plantings in the region.

Addressing potential for commercial adoption. Although asian pear research has been promising, plantings of this crop in the Mid-Atlantic region have been limited. We attribute this to 1) commercial growers are unfamiliar with the asian pears and thus reluctant to plant them and 2) when growers planted asian pears, they frequently chose poorly adapted cultivars. We responded to these challenges by organizing a set of replicated planting sets in 10 research locations. The planting at Wye REC detailed above was repeated at nine additional eastern U.S. locations from Alabama to Massachusetts in 2010. Cooperators in that project completed their data collection in 2015 and are currently summarizing their research findings (data not shown).

Asian pears should be well suited to growers interested in planting this crop in Mid-Atlantic orchards. Due to its field tolerance to fire blight, large fruit size, and good consumer acceptance, Olympic (syn. 'Dan
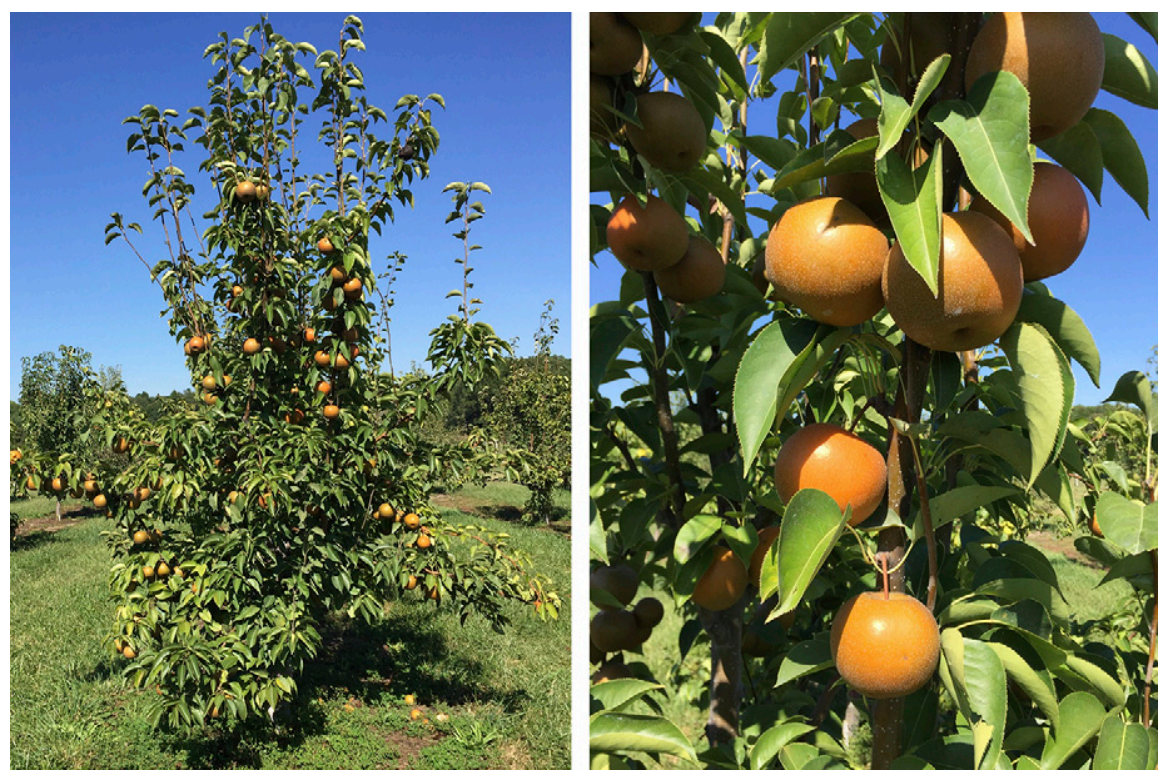

Fig. 1. 'Olympic' asian pear tree on Betulaefolia rootstock in sixth leaf (left) and mature fruit (right) Precocity and sustained annual production have kept tree size manageable, despite lack of size control in the rootstock

Bae' or 'A Ri Rang') released in Korea in 1969 , is the most promising cultivar, and it is the first cultivar recommended to MidAtlantic producers. 'Olympic' also has problems, including internal breakdown in the flesh. As a crop that is harvested tree-ripe, growers wait until optimum ripeness on the tree before harvest. In 2014, summer weather conditions led to early and rapid fruit maturation and internal breakdown in 'Olympic' fruits. To avoid this, growers have been cautioned to harvest 'Olympic' asian pears earlier. Since the original release of Olympic, breeding programs in Japan, Korea, and New Zealand have produced many additional hybrids which should be investigated in the future (White and Brewer, 2002a, 2002b).

In conclusion, while asian pears may not yet be suited to wholesale production and marketing in the eastern United States, they have demonstrated good potential as an alternate crop for direct-market producers involved in the sale of tree-ripe fruit.

\section{Literature Cited}

Hedrick, U.P. 1921. Pears of New York. Report of the New York Agricultural Experiment Station, Volume 2-Part II. J.B. Lyon Company, Albany, New York.

Hogmire, H.W. and C.S. Walsh. 1991. Arthropod pest incidence on sprayed Asian pear cultivars, Proc. West Virginia Horticultural Society.

Miller, A.N. and C.S. Walsh. 1984. The effects of daminozide, bark scoring, and delayed heading on the fruiting of magness pears on Quince-A rootstock. HortScience 19:531.
Oitto, W.A., T. van der Zwet, and H.J. Brooks. 1970. Rating of pear cultivars for resistance to fire blight. HortScience 5:474-476.

O'Rourke, D. 2012. World pear review: The definitive guide to the global pear industry. Belrose, Inc., Pullman, WA.

Pfeiffer, D.G., J.C. Bergh, R.D. Fell, C.R.R. Hooks, G.M. Peck, C.S. Walsh, K.S. Yoder, A.R. Biggs, J.B. Kotcon, J.F. Derr, R.S. Chandran, M.J. Weaver, A. Brown, and J. Parkhurst. 2014. 2014 Spray Bulletin for Commercial Tree Fruit Growers. Va. Coop. Ext. Serv. Publ. 456-419. A regional manual for VA, WV, and MD.

Reimer, F.C. 1915. Blight resistance in pears and pear stocks. California State Hort Commun. Monday Bul. 4:145-149.

Steiner, P.W. 1989. Predicting apple blossom infections by Erwinia amylovora using the MARYBLYT model. Acta Hort. 273:139-148.

Van der Zwet, T. and H. Kiel. 1979. Fire blight a bacterial disease of roseaceous plants. U.S. Department of Agriculture Handbook 510.

Van der Zwet, T. and W.A. Oitto. 1972. Further evaluation of the reaction of 'resistant' pear cultivars to fire blight. HortScience 7:395-397.

Vavilov, N.I. 1951. The origin, variation, immunity and breeding of cultivated plants. Trans. from the Russian by K. Starr Chester. Chronica Botanica, New York, NY.

Walsh, C.S., A.R. Ottesen, M.J. Newell, J.C. Hanson, and E.H. Leone. 2011. The effect of organic and conventional management programs on apple and Asian pear tree growth, productivity, expenses and revenues in a hot, humid climate. Acta Hort. 903:665-672.

White, A.G. and L.R. Brewer. 2002a. Pear breeding in New Zealand. Acta Hort. 587:175-178.

White, A.G. and L.R. Brewer. 2002b. The New Zealand pear breeding project. Acta Hort. 596:239-242. 